\title{
Chapter 3 \\ Who Receives More Help? The Role of Employer Support in Migration Processes
}

\author{
Laure Sandoz and Fabian Santi
}

\subsection{Introduction}

Why are white people expats when the rest of us are immigrants?

This question, raised by the African social activist Mawuna Remarque Koutonin in the Guardian in March 2015, critically addresses the problematic dimension of the categories that we commonly use when we talk about mobile people. Although "immigrants" are typically represented as poor, ethnically marked low-skilled people, "expats" tend to be imagined as white, wealthy, highly skilled individuals who easily travel from one country to another according to their job (Favell et al. 2006; Al Ariss and Crowley-Henry 2013; Cranston 2017). These stereotypical representations are problematic in many respects, but they reflect nonetheless the global inequalities and power relations that currently structure migration processes.

This article highlights some of these inequalities by focussing on the support that different groups of migrants receive when they move to Switzerland. Drawing on both an ethnographic study and the nccr - on the move Migration-Mobility Survey, we want to understand how different actors structure different forms of migration for different categories of people. We focus in particular on the relocation support that labour migrants receive from their employer when they come to Switzerland. We contribute to the theoretical framework of the Migration-Mobility Nexus by examining how the mobility practices of companies intersect with the Swiss

\author{
L. Sandoz $(\bowtie)$ \\ nccr - on the move, Neuchâtel, Switzerland \\ e-mail: Laure.Sandoz@unine.ch \\ F. Santi \\ University of Neuchâtel, Neuchâtel, Switzerland \\ e-mail: Fabian.Santi@unine.ch
}


migration system to create differentiated pathways of inclusion and exclusion according to social characteristics such as gender and nationality.

Relocation support not only facilitates adjustment to a new environment (Ravasi et al. 2015) but also motivates and enables a move (Van den Broek et al. 2015; Harvey et al. 2017; Groutsis et al. 2015). Support is particularly important for the third-country nationals who want to migrate to Switzerland because the restrictive admission system limits access to residence permits for this category of people. Labour migrants from third-countries can only be admitted if they are supported by an employer. In addition, candidates for family reunification need support from a family member with a right to stay in Switzerland (Amarelle and Nguyen 2010). Analysing the role of support agents for recent migrants in Switzerland thus enables us to better understand how opportunities and obstacles to mobility and social inclusion are constructed. Observing which categories of people receive more support from employers informs us about who has more power to negotiate advantageous relocation conditions and, in this sense, represents a more "wanted" migrant for profit-oriented actors.

We start this article by discussing the construction of migrant categories in the academic literature. We then present our methodology, which draws on both ethnographic and survey data. We introduce in Sect. 3.4 our main hypotheses by combining findings from the literature, interview quotes from the ethnographic study and the descriptive analysis of the survey data. We finally present in Sect. 3.5 a model based on a logistic regression to test these hypotheses, and we discuss their relevance with respect to our main research questions. We conclude this article by arguing that definitions of "wanted" migrants must consider the practices of various actors, including the employers who select and attract people according to their immediate needs.

\subsubsection{Defining the "Wanted" Migrants}

Most of the categories that researchers use to define people on the move arise from the historical construction of nation-states (Favell 2008). Several authors in recent years have argued that the representation of citizens as sedentary subjects that differ from migrants based on the rights and privileges granted to them by the state is not sufficiently reflected upon in the academic literature (Dahinden 2016; Fassin 2011; Favell 2008). These authors acknowledge the central influence of political categorizations in migration processes, but they encourage researchers to maintain a critical stance to allow research to remain an independent field of knowledge production rather than a tool in the service of states (Hercog and Sandoz 2018a). They remind us that although political constructions such as nationality shape the possibilities of individuals to move and stay in different places (Wagner and Reau 2015; Kaufmann et al. 2004), these categories are not neutral because they rely on political, economic and social dynamics that normatively construct migrants according to culturally situated values. In a global world shaped by selective borders, the recent popularity 
of the opposition between "highly skilled" and "low-skilled" migrants relies for instance on the emergence of skill-focussed immigration programmes in the 1960s whose objective was to attract "the best and the brightest" individuals and prevent the immigration of "unwanted" people (Parsons et al. 2014; De Haas et al. 2016). These new approaches to migration management have given rise to what Shachar (2006) has called the "Race for Talent", and they have contributed to new categorizations of migrants as either "highly skilled" or "low skilled".

Although approaches that critically analyse migrant categories remain rare in the social sciences (Hercog and Sandoz 2018a; Favell 2008), several authors have contributed to this field by reflecting on the problematic dimensions of some commonly used categorization processes. They have shown that, although policies that select migrants based on their skill levels are often perceived as less discriminatory than other selection tools because of their merit-based approach, they nonetheless lead states to discriminate between migrants according to criteria such as their race (Tannock 2011), cultural closeness (Yeung 2016) and social desirability (Hercog and Sandoz 2018b; Simon-Kumar 2015). Moreover, oppositions between "highly skilled" and "low skilled" migrants raise important issues concerning the value given to different forms of knowledge in a world in which power is unequally distributed across places and social groups (Wagner 2007). The gendered bias of skillselective policies and the disadvantages they entail for women have also been highlighted by several researchers (Kofman and Raghuram 2005; Boucher 2007; Kofman 2014). Finally, some authors have argued that the value and rights attributed to different groups of migrants rely more on decision makers' perception of a given situation than on the migrants' actual characteristics (Hercog and Sandoz 2018a, b; Sandoz 2018a). These different studies show that keeping a critical stance towards categories is important to avoid reproducing or legitimizing discriminatory systems of representation.

Critical approaches towards migrant categories usually focus on the role of states in managing, naming and counting moves (Favell 2008). However, researchers have highlighted the growing influence of non-state actors in the process of selecting, supporting and employing migrants (Groutsis et al. 2015; Cranston et al. 2017). Many countries, including Switzerland, currently use demand-driven systems and partly delegate the task of selecting migrants to employers (Chaloff and Lemaitre 2009; Parsons et al. 2014). In these systems, the employers are responsible for applying for the admission of the candidates they want to hire, and they thus contribute to defining the "wanted" migrants who can obtain access to the national territory and labour market (Gelatt 2017).

Examining the type of support that different groups of migrants receive from their employer is an interesting approach to assessing who obtains more-privileged access to migration in the context of a demand-driven system such as that of Switzerland. It indicates whom the employers are most willing to attract in spite of the administrative hurdles of the admission process. Moreover, such an examination hints at who obtains smoother access to Swiss territory because the relocation support provided by employers also aims to facilitate transitions between places and to ease adjustment processes (Tissot 2018; Ravasi et al. 2015). 
This article contributes to the literature on the construction of migrant categories by analysing the specific role of employers in supporting certain categories of migrants and thus constructing them as "expats" who differ from other migrants due to their professional situation and the other advantages that derive from such a status. In light of Mawuna Remarque Koutonin's quote presented at the beginning of this article, we argue that how various social actors perceive the social characteristics of migrants is central to defining them as wanted or unwanted, welcome or unwelcome.

\subsubsection{Methodology}

We use a mixed-method approach, combining the quantitative analysis of the Migration-Mobility Survey with an ethnographic study conducted by Laure Sandoz as part of the nccr - on the move project "The Mobility of the Highly Skilled towards Switzerland" (Sandoz 2018b). This combination enables us not only to highlight the main variables that structure access to employers' support for our population but also to understand some of the social and cultural logics that lead employers to give preference to some categories of migrants.

The ethnographic study was conducted between 2014 and 2018 in the two Swiss regions of Basel and the Geneva Lake Area. It focussed on the strategies of institutional actors from the public and private sector to select, attract and retain mobile individuals who represent value to them. It included 16 semi-directed interviews with professionals who work for institutions that have a stake in attracting, selecting or retaining migrants in Switzerland, 13 biographical interviews with people who moved to Switzerland under the auspices of such institutions, and numerous observations at events that aim to inform and support highly skilled migrants in Switzerland. This article primarily draws on eight semi-directed interviews of $1-2 \mathrm{~h}$ conducted as part of this research with human resources staff, professional recruiters and relocation agents about their daily practice of recruiting and facilitating the relocation of foreign employees in the two regions under study. We selected them for this article because of their relevance to the discussed topic. Biographic interviews with migrants who relocated to Switzerland with the support of their employer and ethnographic observations at events targeted at highly skilled migrants and their families further inform this article by providing additional data on how employers' support is perceived and experienced by the people who benefit from it.

The survey analysis focussed on the relocation support that respondents to the survey reported. The population under study consists of people from German-, French-, Italian-, English-, Spanish-, and Portuguese-speaking countries who arrived in Switzerland during the past 10 years (for more information about the survey design, see Chap. 2 of this book). The survey is weighted to represent the migrant population in Switzerland within the scope of the survey. Throughout this chapter, the computation of numbers considers these weights. The numbers or ratios 
reported are thus the expected values based on the whole population within the scope of the survey.

The survey participants were initially asked the following question:

When moving to Switzerland, did you receive any support in one of the following areas?

(Multiple answers are possible)

Respondents had the choice between "yes", "no" and "not applicable" for each support category. However, we noticed that the respondents understood the difference between "no" and "not applicable" in different ways. For instance, respondents without children occasionally replied "no" and occasionally replied "not applicable" to the question of whether they received support for school or childcare. We thus decided to recode the "not applicable" answers as "no" to ensure homogeneous treatment of the data.

This first question was asked of all of the survey participants $(n=5973)$, but only the respondents who replied "yes" to at least one support category $(60.1 \%)$ were asked the second, following question:

From whom did you receive support? (Multiple answers are possible)

We thus recoded the second variable about sources of support to include the whole survey population in both questions (we considered the $39.9 \%$ of filtered respondents from the first question as having replied "no" in the second question). Our analysis specifically focussed on the people who reported support from their employer.

When presenting numbers for specific subgroups of the population, based on factors such as gender, qualification level and nationality, we highlight differences between these groups and determine which properties define those differences best. To confirm the relevance of the differences observed between groups, we apply a Chi-square test of independence after re-weighting the data using normalized weights. P-values are reported at the $5 \%, 1 \%$ or $0.1 \%$ levels. Because the results of the statistical tests using this method are approximate, a conservative approach should be taken in evaluating the power of the statistical tests.

We then use a weighted logistic regression in Sect. 3.5 to evaluate the effect of different variables while controlling for the other factors. This approach allows us to verify our hypotheses, which are developed in the presentation of the ethnographic study and the data. The regression presents and summarizes our findings in a single coherent model.

The dependent binary variable in the logistic regression is whether the respondents received support from their employer when they moved to Switzerland. The independent variables are qualification level ${ }^{1}$ (highly qualified (reference category), less qualified), gender (men (ref), women), relationship status (married or in a rela-

\footnotetext{
${ }^{1}$ We define highly qualified people as people with either advanced technical and professional training or an academic education. Less qualified people are people with a high-school education, vocational training or less.
} 
tionship when coming to Switzerland (ref), not married or in a relationship when coming to Switzerland), nationality ${ }^{2}$ and professional sector. ${ }^{3}$ Moreover, we use as control variables possession of a job or a job offer in Switzerland before the migration (or not), age, ${ }^{4}$ presence of children (or not) and occupational status. ${ }^{5}$

To choose our categories of reference, we imagined a person who corresponds to the usual stereotype of an "expat" receiving particularly high degrees of support. We refer directly to Mawuna Remarque Koutonin's critique about the construction of differences between "immigrants" and "expats" based on race, class, nationality and gender, and we want to check to what extent employers reproduce these stereotypes when attributing relocation support. In light of the literature on discrimination and social inequalities, we expect the most "wanted" migrants to be highly qualified married men from Anglo-Saxon countries working in socially valued sectors and having managerial responsibilities. We are particularly interested in observing how these different parameters influence access to employers' support in a model that controls for the effect of all of the other variables involved.

Hence, the statistical analysis enables us to discuss the role of employers' support on the relocation to Switzerland of recent migrants from the main immigration countries, whereas the ethnographic study enables us to discuss these results in the light of direct experiences from the field.

\subsection{Access to Support: Data, Variables and Hypothesis}

Access to support from an employer, family member, friend or organization can constitute an important motivation to migrate (Piguet 2013; Groutsis et al. 2015). In Switzerland, a large share of the economy relies on the expertise of foreign professionals (Haug and Müller-Jentsch 2008; Mach et al. 2011), and companies play a major role in attracting migrants (Davoine et al. 2015). To this end, they have

\footnotetext{
${ }^{2}$ The origin includes, based on the nationality Germany, France, Italy, Austria, Spain, Portugal, United Kingdom, United States, Canada, India, Brazil, West Africa (Benin, Ivory Coast, Guinea, Mali, Niger, Burkina Faso, Senegal, Togo, Gambia, Ghana, Liberia, Nigeria, Sierra Leone, Saint Helena, Guinea-Bissau, Cape Verde, Sao Tome and Principe) and other South American countries (Argentina, Bolivia, Chile, Ecuador, Colombia, Paraguay, Peru, Uruguay, Venezuela and Guyana). ${ }^{3}$ The professional sector includes the following categories: agriculture, forestry and fishing; construction; wholesale and retail trade, transportation, hotels and restaurants; public administration, defence, education, human health and social action; information and communication; professional, scientific, technical, administration and support service activities; financial and insurance activities; manufacturing, mining and quarrying and other industry; and other activities and services.

${ }^{4}$ The age is taken as 2018 minus the year of birth, as given in the survey, and as a whole number.

${ }^{5}$ Occupational status includes the following categories: self-employed workers; company owners; relatives employed in a family business; directors or board members and/or with managerial responsibility; people employed without managerial responsibility; people employed in a protected workshop (except support staff); apprentices; and PhD students.
} 
developed various strategies to access the employees they need the most (Ravasi et al. 2015; Van den Broek et al. 2015).

Support in the form of relocation services provided directly by the employing companies or through relocation agencies mandated by the employers constitutes one of these strategies (Davoine and Salamin 2012; Sandoz 2018b; Tissot 2018). Before the migration, the promise of a generous relocation package and positive information about the new environment can help convince a promising candidate to accept a new position. During the relocation, services such as the payment of moving costs and support for administrative issues can help alleviate the constraints associated with migration. After the relocation, services such as spouse employment support and payment for language courses can facilitate adaptation to the new environment. These services enable employers to attract and keep the employees they want most by constructing migration as a smooth and easy process (Tissot 2018). Moreover, they contribute to positioning the people who benefit from such services in a privileged social situation in comparison to other migrants. This quote from an interview with a human resources manager about relocation practices in the banking sector nicely illustrates this situation:

If you want to be professional, you have to mandate a [relocation] agency. But agencies are expensive! And then you give them [the relocating employees] the feeling to be expats. And in the head of expats it's: I want an expat contract and the school for the children, the private school. [...] So, if he has a rare skill, he wants 100,000 for the school, he wants the accommodation ... it's a bit deterring for the employer (Human resources staff, 11 April 2015).

Employers usually use economic arguments to explain how they attribute relocation support to their employees; although relocation packages are expensive, they become worthwhile if they enable a company to access employees who can bring more value than what attracting them cost (Davoine and Salamin 2012). Under this logic, the relocation support received by employees can be considered a measure of their skills' value for the company.

However, the negotiation of relocation packages also involves other mechanisms (Sandoz 2018b). For instance, the employees must be aware of their value to negotiate advantageous relocation conditions at the moment of their employment. Relocation packages thus also give indications about the position and negotiation power of relocating employees with respect to their employer. Moreover, the value of an employee's skills is very context-dependent because it relies on the company situation, the skills' rarity and the difficulty for the employer to obtain them. The following quote illustrates this complex situation:

If he's someone with a commercial approach, you know how much he costs, you know how much profit he can make, you can calculate, you can objectivize. But it is not always easy to estimate. But if he's a super professional with very specialized skills, he is the only one in Europe who can do the thing, he lays down his conditions. He lays down the market conditions (Human resources staff, 11 April 2015).

Of course, not all migrants have access to the support of an employer. In our survey, although a majority of the respondents declared that they had moved to Switzerland 


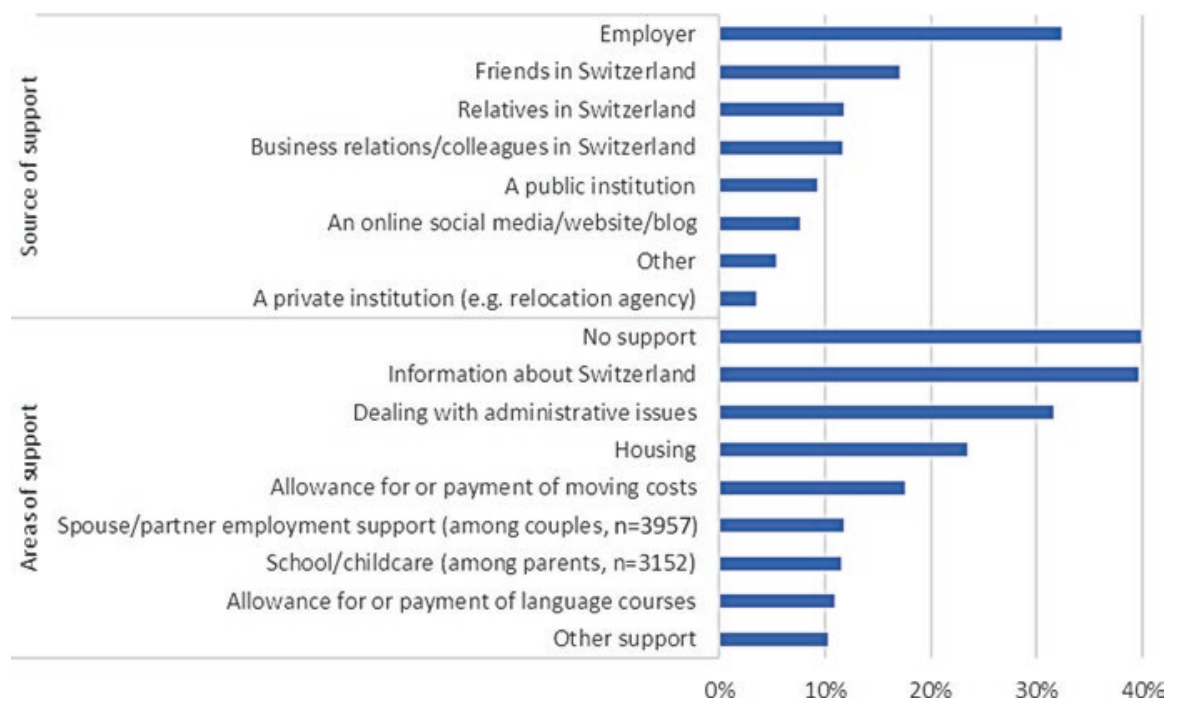

Fig. 3.1 Main sources and areas of support received by migrants, Switzerland Source: Migration-Mobility Survey 2016. Weighted results

for professional reasons $(61.6 \%)$, and more than half of them had obtained a job or a job offer in Switzerland before coming (52.2\%), only one-third reported support from an employer. Moreover, nearly $40 \%$ of them reported no support at all. Although the employers nonetheless clearly constitute a major source of support for recent migrants in Switzerland, Fig. 3.1 shows that the respondents to our survey could also rely on the help of other actors for organizing their move to Switzerland, in particular their personal contacts such as friends, relatives and business colleagues.

To better understand the effect of the employers on relocation support, we compared the situation of people who had received some type of support from their employer with that of people who had not. Table 3.1 shows that people who could rely on their employer had, in general, access to more services than did those who relied on other sources of support, in particular with respect to financial support for organizing their move, support for finding accommodation and addressing administrative issues, allowances for language courses and access to schooling or childcare. This descriptive analysis shows that support from employers provides access to specific resources and services that are less available to migrants who rely on other forms of support.

Although these findings highlight the important role played by employers in providing relocation support, they also show that such support is not available to every migrant. It is therefore important to understand whom this support prioritizes and what other resources are available to people on the move. 
Table 3.1 Effect of employer support: comparison between migrants who declared support from their employer and migrants who did not declare any support from their employer but who received support from (an)other source(s)

\begin{tabular}{l|l|l|l}
\hline & $\begin{array}{l}\text { Support from the } \\
\text { employer }\end{array}$ & $\begin{array}{l}\text { No support from } \\
\text { their employer }\end{array}$ & P-Value \\
\hline $\begin{array}{l}\text { Allowance for or payment of } \\
\text { moving costs }\end{array}$ & $47.9 \%$ & $12.5 \%$ & $\begin{array}{l}<0.001 \\
\left(\mathrm{X}^{2} ; \mathrm{N}=3265\right)\end{array}$ \\
\hline Housing & $53.0 \%$ & $28.7 \%$ & $\begin{array}{l}<0.001 \\
\left(\mathrm{X}^{2} ; \mathrm{N}=3315\right)\end{array}$ \\
\hline $\begin{array}{l}\text { Dealing with administrative } \\
\text { issues }\end{array}$ & $65.4 \%$ & $41.5 \%$ & $\begin{array}{l}<0.001 \\
\left(\mathrm{X}^{2} ; \mathrm{N}=3440\right)\end{array}$ \\
\hline $\begin{array}{l}\text { Allowance for or payment of } \\
\text { language courses }\end{array}$ & $29.8 \%$ & $14.8 \%$ & $\begin{array}{l}<0.001 \\
\left(\mathrm{X}^{2} ; \mathrm{N}=2847\right)\end{array}$ \\
\hline $\begin{array}{l}\text { School/childcare } \\
\begin{array}{l}\text { Spouse/partner employment } \\
\text { support }\end{array}\end{array}$ & $20.6 \%$ & $16.4 \%$ & $\begin{array}{l}<0.05 \\
\left(\mathrm{X}^{2} ; \mathrm{N}=2047\right)\end{array}$ \\
\hline Information about Switzerland & $68.9 \%$ & $26.0 \%$ & $\begin{array}{l}<0.001 \\
\left(\mathrm{X}^{2} ; \mathrm{N}=2474\right)\end{array}$ \\
\hline Other support & $23.5 \%$ & $67.1 \%$ & $\begin{array}{l}\text { Not significant } \\
\left(\mathrm{X}^{2} ; \mathrm{N}=3464\right)\end{array}$ \\
\hline
\end{tabular}

Source: Migration-Mobility Survey 2016. Weighted results

A comparison between these findings and those of a study by Ravasi et al. (2015) - who focussed exclusively on the relocation services that 12 multinational companies in the French-speaking part of Switzerland offer to their highly qualified employees - suggests differences in terms of qualification level, professional sector and types of companies. Support availability is much higher in their study than in ours (financial support for moving costs was for instance available to $94.1 \%$ of the respondents in their study, against $17.6 \%$ in ours). These differences point to a significantly higher degree of relocation support in multinational companies, which encourages examining the specificities of professional sectors. Moreover, both our ethnographic observations and the literature in this field point to the effect of nationality and gender on selection processes within companies.

We thus propose to analyse differences in access to relocation support for various categories of migrants, in particular according to their qualification level, gender, nationality and professional sector. We want to understand who obtains access to more relocation support in the context of the Swiss immigration system and thus constitutes a more "wanted" category of migrant in the eyes of the employers. In the following paragraphs, we discuss the potential effect of different variables in the light of the literature and based on our ethnographic observations and descriptive statistical analyses. This discussion introduces the model that we use in Sect. 3.5 to test our hypothesis. 


\subsubsection{Qualifications}

The descriptive analysis of our survey data suggests that access to relocation support is closely connected to the level of education. As shown in Fig. 3.2, highly qualified migrants are more often supported by their employer than are less qualified people, whereas less qualified people receive more support from relatives in Switzerland. These data indicate a stronger dependency of less qualified migrants on kinship networks, whereas highly qualified people more often rely on the support of their employer. Support from friends and colleagues, however, is more evenly distributed between the different categories and indicates no clear correlation with the qualification level.

Although this observation is interesting, we hypothesize that it only reveals part of the story. As many other authors have shown, qualifications are only one of the signals that employers use to evaluate candidates for employment (Findlay et al. 2013; Zschirnt and Ruedin 2016). Perceptions and stereotypes associated with the nationality, ethnicity, gender, family situation and age, among other variables, contribute to defining the value of candidates during recruitment processes. We thus hypothesize that they also influence access to relocation support.

In the logistic regression presented in Sect. 3.5, we distinguish between highly qualified and less qualified migrants, and we expect this variable to have a significant effect on the support offered by employers. However, we do not expect this variable to have more effect than other variables less directly linked to skills, such as nationality. We assume that, in contrast to economistic discourses that conceive

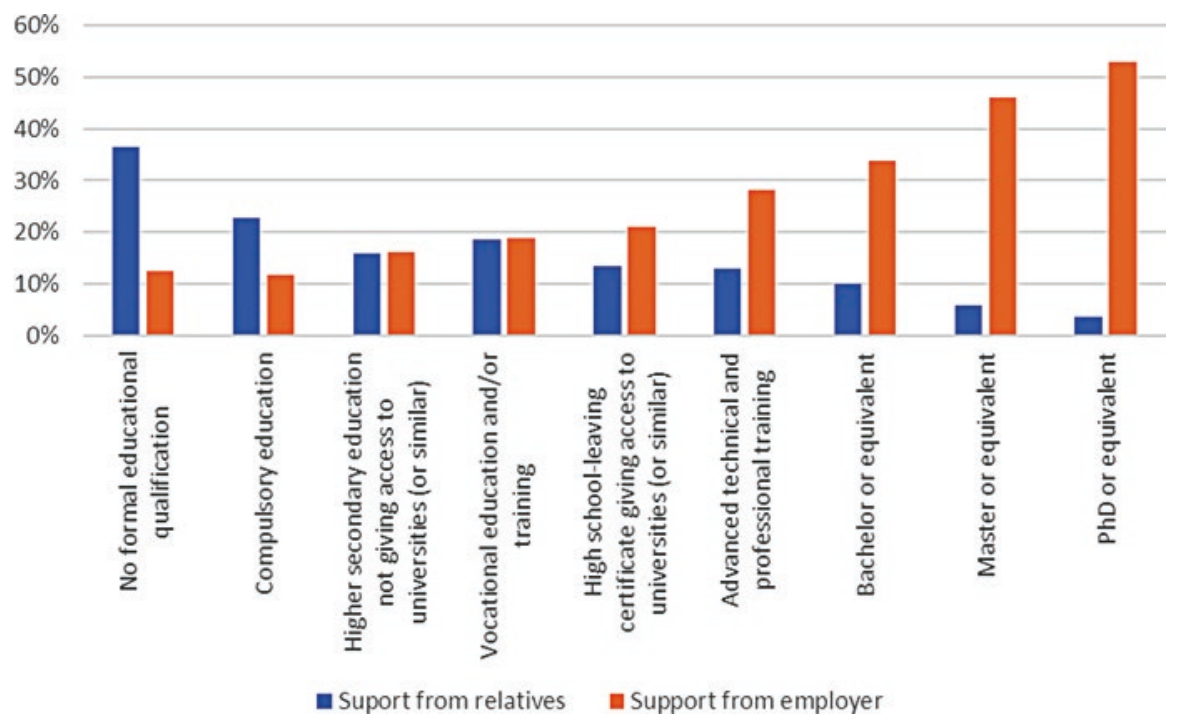

Fig. 3.2 Support received by migrants from relatives and employers by level of qualification, Switzerland Source: Migration-Mobility Survey 2016. Weighted results 
skills as purely marketable products obeying clear economic logics (Urciuoli 2008), representations of "wanted" migrants involve more than a simple evaluation of a person's competences. Beyond what a person can do, what a person is or appears and the social, political and economic contexts in which this person moves influence the types of resource and privilege that s/he can access (Hercog and Sandoz 2018a).

\subsubsection{Gender and Relationship Status}

Gender is without any doubt indispensable for analysing the issue of access to employers' support. However, it is important to distinguish between differences that rely on structural factors and differences that rely on direct discrimination by the employers.

Although many authors have noticed an increase in the number of female-led relocations and dual-career couples over the past decades (Salamin and Davoine 2015; Crompton and Lyonette 2006; Harvey et al. 2009; Brookfield 2016), our survey data clearly show that the dominant model in Switzerland remains that of the woman following her partner. Although both men and women respondents reported professional reasons to be their main motivation for migrating to Switzerland, we observe that men more often migrated for professional reasons (70.4\% vs $50.4 \%)$, whereas women more often migrated to accompany family ( $29.3 \%$ vs $7.5 \%$ ). Moreover, $62.9 \%$ of the men had already found a job in Switzerland before migrating, against only $38.5 \%$ of the women.

Of course, this situation has implications for the type of support received by men and women. In fact, the data show that men received more support than women did in all of the surveyed categories except for "spouse/partner employment support", "school/childcare" and "other forms of support". Not surprisingly given their main migration reasons, women more often reported having been supported by relatives in Switzerland than did men (13.7\% vs $10.2 \%)$, whereas men more often reported having been supported by their employer than did women (37\% vs $26.4 \%$ ).

These data clearly indicate the existence of structural gendered norms within couples that lead women to give priority to the career of their male partner over their own. They thus point to the importance of the intersection between gender and relationship status for structuring access to relocation support. However, they say nothing about processes of direct discrimination by employers. In fact, our descriptive analysis rather points to the absence of discrimination towards single women because the comparison between men and women who migrated as single people indicates no significant difference in terms of access to employers' support (Table 3.2).

Nevertheless, the important literature on gendered recruitment and skill valuation processes encourages us to dig further into the case of potential discrimination towards women by employers. A recent study in Sweden showed for instance that employers are reluctant to hire women who live a long distance from the workplace, whereas men in the same situation encounter no such obstacles (Brandén et al. 2018). Moreover, many studies have highlighted the tendency of employers and 
Table 3.2 Support received by migrants from the employer according to gender and relationship status when moving to Switzerland

\begin{tabular}{l|l|l|l}
\hline & Men & Women & P-value \\
\hline Married or in a relationship & $38.9 \%$ & $23.7 \%$ & $<0.001\left(\mathrm{X}^{2} ; \mathrm{N}=3973\right)$ \\
\hline Not married or in a relationship & $33.5 \%$ & $32.8 \%$ & $\begin{array}{l}\text { Not significant } \\
\left(\mathrm{X}^{2} ; \mathrm{N}=1999\right)\end{array}$ \\
\hline
\end{tabular}

Source: Migration-Mobility Survey 2016. Weighted results

other actors to evaluate skills differently depending upon whether they are associated with a man or a woman (Steinberg 1990; Phillips and Taylor 1980; Boucher 2007; Kofman 2014; Jenson 1991; Daune-Richard 2003). If the value of relocation packages derives from the value that employers attribute to their employees, we can expect in the light of these studies to observe a disadvantage for women, even in cases in which we control for the effect of other important variables.

At the same time, our interviews with relocated couples and employers point to other dynamics. They suggest on the one hand that the gender norm according to which men must be professionally active remains strong even in couples in which the woman initiated the relocation. This situation leads some women to firmly negotiate their relocation conditions at the moment of their employment to ensure that their partner gets sufficient support to remain economically active despite his position as a trailing spouse (Sandoz 2018b). Although these ethnographic observations do not enable generalizations at the level of a population, they can contribute to explaining situations in which women obtain access to more relocation support than their male counterparts do.

On the other hand, employers are aware that many relocations fail because the spouse is not satisfied with his or her new situation (Salamin and Hanappi 2014). We see this phenomenon for instance in this quote from the human resources manager of a bank:

The man who works for us, if his wife is not happy, the children are a bit lost at school and everything, it's not going to work. So you know that if you want to keep them, you have to organize a complete relocation of the family with all the proper rules. It costs you an arm and a leg, you're not sure that it will succeed (Human resources staff, 11 April 2015).

The interviewee explicitly refers to a situation in which the man is the lead and the woman follows. He mentions the difficulty of keeping the new employee if the partner remains unemployed. He also explains that the costs of moving both partners are particularly high. Between the lines, he suggests another idea that came up in many other interviews, which is that when employees leave shortly after the relocation, the company loses the money they invested for attracting them. In situations in which the main candidate for relocation is a woman and the trailing partner is a man, we might expect employers to be even more reluctant to take the risk of investing in an expensive relocation because they might consider that the risks for a male unemployed partner to be unhappy and want to leave are even higher because of the effect of gender norms (Harvey and Wiese 1998; Mancini-Vonlanthen 2016). They 
might thus decide either to invest more resources to support the professional integration of the male trailing spouse or to reduce the costs of the relocation to limit the losses for the company in the event of an unexpected departure of the female employee.

We are thus particularly interested in observing the effect of gender on employers' relocation support in the logistic regression in Sect. 3.5 that controls for other important variables. We hypothesize a difference that is more strongly connected to the interaction between the relationship status and gender than with gender alone because a large part of the observed differences between men and women appears to rely on the interaction between couple dynamics and structural gender norms. However, in light of the literature, we would not be surprised to observe differences that suggest more-direct forms of discrimination towards women from the employers.

\subsubsection{Nationality}

Opportunities to migrate, to be recruited by an employer and to receive relocation support greatly vary amongst nationalities. One main reason for this variation is the existence of national border regimes that discriminate between countries and regions (Hercog and Sandoz 2018b). In Switzerland, only "qualified workers from third countries who are absolutely needed" and who have a job contract in Switzerland are in principle allowed to enter the Swiss labour market (Swiss Federal Council 2002). In contrast, citizens from the European Union (EU) and from countries belonging to the European Free Trade Association (EFTA) can freely stay and work in Switzerland, as long as their personal resources allow doing so (Sandoz 2016). This dual admission system contributes to structuring migration flows to Switzerland. On the one hand, people from third-countries need special assistance from their employer if they want to migrate to Switzerland as labour migrants; on the other hand, this system encourages the employers to prioritize recruitment from within the EU/EFTA and only to attract specialists that they need the most from thirdcountries. Given this specific legal regime, we can expect that labour migrants from third-countries who come to Switzerland with a job will receive more support from their employer than will EU/EFTA migrants because they constitute a category of particularly "wanted" migrants from the perspective of the employers.

However, beyond immigration policies, we also must consider the effect of social and economic processes on the position of different nationalities. The transferability of skills is never neutral because it reflects power relations at a global level that enable the characteristics associated with certain regions and countries to be perceived as internationally more valuable than others are (Wagner and Reau 2015; Sommer 2016). For instance, the privileged position of the English language in international environments reflects the leading economic and cultural influence of the United States in the world. As the sociologist Anne-Catherine Wagner (1998) says, "the relations between nationalities present similarities with the relations 


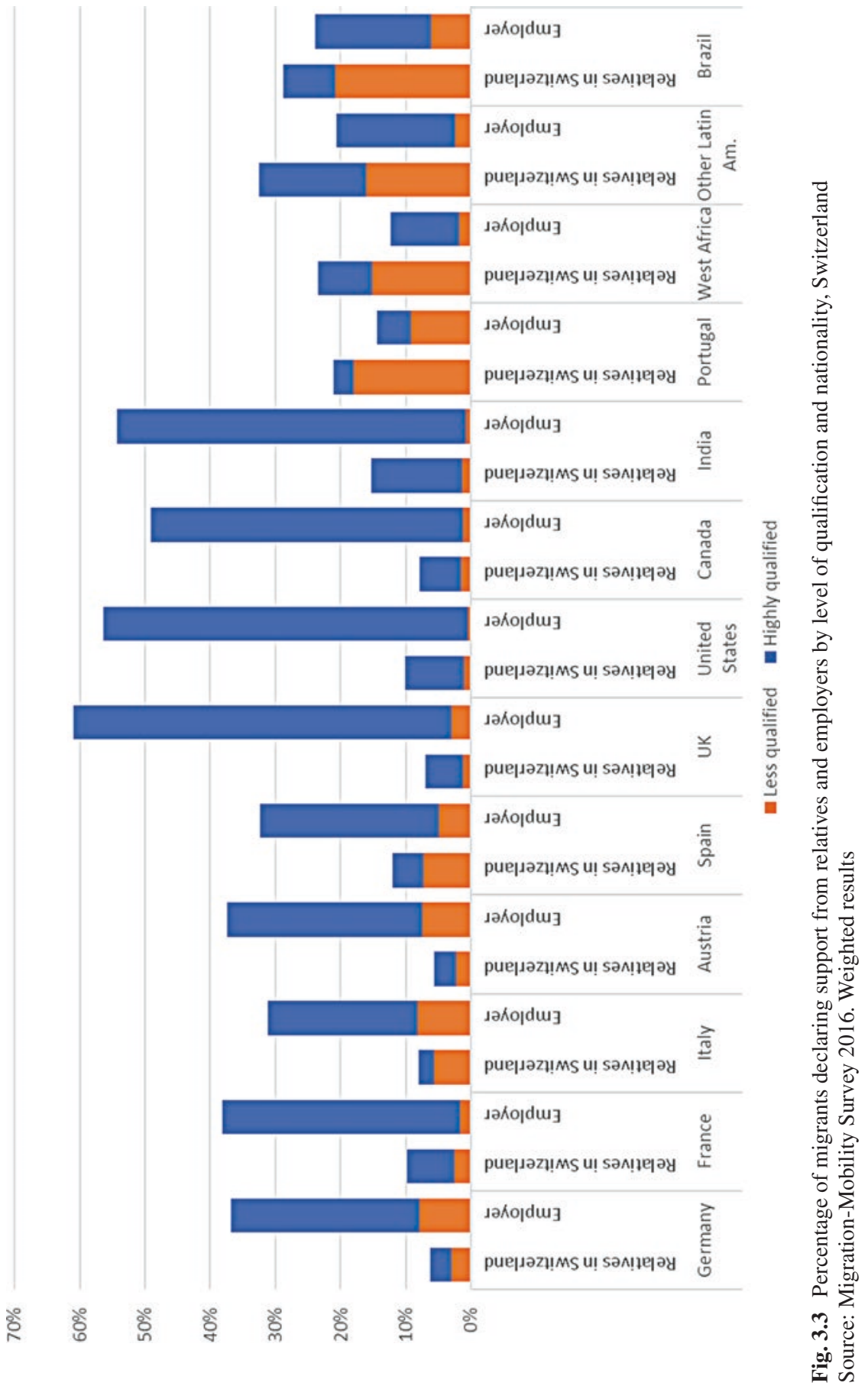


between social classes within a country. Those who can assert the 'international' value of their national attributes oppose those who rather tend to repress them in order to adapt to dominant norms" (own translation by the authors).

Consistent with this observation, the descriptive analysis of our survey data presented in Fig. 3.3 clearly shows that both nationals from Anglo-Saxon countries and people from Switzerland's neighbouring countries receive on average more support from their employer than people from less economically powerful countries do. It does not mean that people from this second group receive no support at all, but they tend to receive it more from their relatives in Switzerland than from an employer. At the same time, we observe that the recent emergence of certain developing countries as major global economic players and workforce providers in specific fields - for instance, India in the field of science and information technologies (Swiss Federal Department of Foreign Affairs 2017; Xiang 2007; Hercog 2014) - has produced new groups of well-supported professionals who challenge the classical representations of the "expats" as white individuals coming from western countries (Kunz 2016; Pavic 2015). In this sense, the strict Swiss admission system for third-country nationals interacts with economic dynamics and global power relations to create different possibilities for different nationalities to migrate and to be supported. We see this variation clearly in this quote from the interview with a professional recruiter working for the life sciences business:

After a while, I stopped looking outside of Europe. [...] We always looked at nationality. [...] If there was a country outside of Europe where we searched more, it was the United States. But it's true that it was complicated. Then, if it was the right person, it was possible. But it really had to be the perfect profile (Professional recruiter, 5 February 2015).

The logistic regression presented in Sect. 3.5 enables us to go one step further and test the influence of nationality on access to employers' support while controlling for the effect of other important variables. Consistent with the previous discussion, we expect people from the United States and other Anglo-Saxon countries to be particularly well supported by their employer in comparison with people from less economically powerful regions such as West Africa and Latin America. However, we would also expect people from neighbouring countries to receive less relocation support than would people from more-distant, non-EU countries because Switzerland is more accessible for them due to both geographical proximity and the free movement of persons system.

\subsubsection{Professional Sector}

A last important aspect that must be considered when analysing access to relocation support concerns the recruitment practices of employers in specific professional sectors. As the migration researcher Robyn Iredale (2001) notes, "The type and level of regulatory mechanisms, the level of internationalization and the relative influence of the market, the state and the profession, and the global labour market demand/supply situation are all very significant factors in explaining migration". 
These factors also contribute to explaining differences in access to relocation support. In particular, how economic actors define needs and shortages in certain sectors influences the amount of resources that they are willing to invest to attract workers (Findlay et al. 2013; Ruhs and Anderson 2010). Hence, relocation support is granted not so much according to an individual's level of skill as according to the skills' perceived rarity and necessity in a specific economic context and according to the specific position and negotiation power of the employee. As one of our interviewees working in the human resources department of a chemical company said:

I think that the definition of highly skilled depends basically on the skills that are on the local labour market [...]. So you might consider that the skills of a CEO are relatively low if you can easily find somebody like a CEO on your local labour market (Human resources staff, 18 February 2015).

In addition, access to support relies on the companies' internal relocation policies, which often depend upon their internationalization degree and dependence upon a foreign workforce (Iredale 2001). We have seen for instance that multinational companies tend to more systematically offer relocation services than other companies do (Ravasi et al. 2015). However, the current tendency among multinational companies consists of reducing the costs associated with such services (Le Temps 2015; Davoine and Salamin 2012; Cartus 2014). We can thus expect to observe differences between professional sectors that have more to do with internal management decisions and priorities than with clearly identifiable economic factors.

To illustrate these aspects, Fig. 3.4 suggests that some differences in support rely on the specificities of the professional sectors, although we also observe a relationship between the level of qualification and the support received from either the employer or relatives in the different sectors. For instance, the respondents working in "information and communication" reported less support from their employer than did the respondents in "manufacturing, mining and quarrying and other industry", although $84.1 \%$ of the people in the first sector have a higher education against $74.3 \%$ of the people in the second sector. Moreover, a further analysis highlights specific recruitment channels within some activity sectors. For instance, nearly onethird of all of the Indians work in the "information and communication" sector and report very high degrees of support from their employer. We also noticed that a surprisingly high share of low-qualified migrants from Portugal had reported support from an employer in the construction and agriculture sectors, indicating that not only highly qualified migrants are being actively recruited towards Switzerland.

Nevertheless, the logistic regression in Sect. 3.5 that analyses differences in support between professional sectors also must consider other variables because relocation support partly depends upon a person's hierarchical position, level of responsibility and type of occupation within a company (Davoine and Salamin 2012). We can expect some categories of workers, for instance self-employed workers and company owners, to receive significantly less employer support compared with other categories of workers. We thus control inter alia for the effect of occupational status in our model, to observe whether differences in support between professional sectors persist and, if true, which sectors offer more support to their employees. 


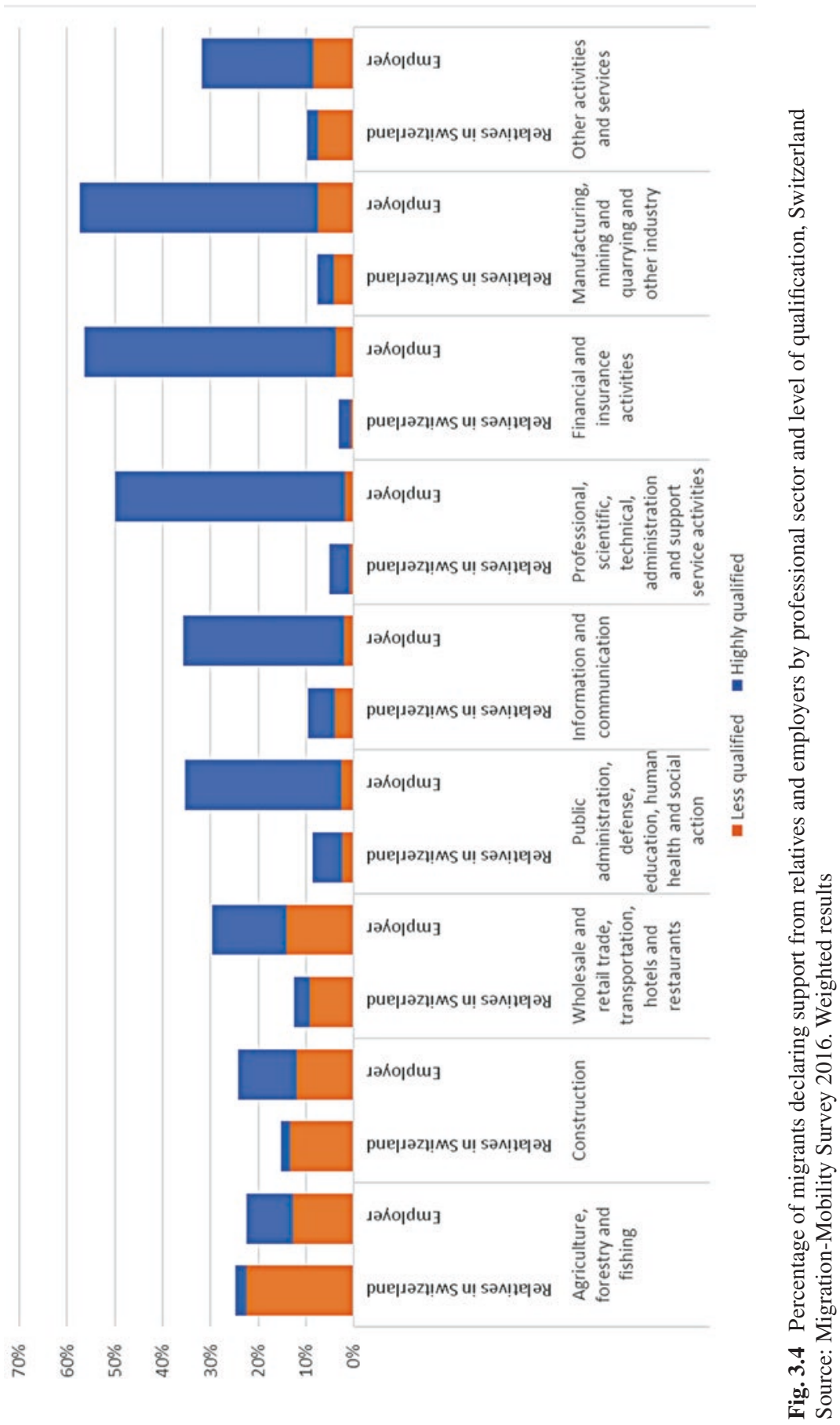




\subsection{Determinants of the Employer Support}

The results of the logistic regression on employer support are presented in Table 3.3.

The effect of the qualification level is, as expected, highly significant. With all of the other variables being equal, the probability of receiving the support of an

Table 3.3 Effect of different variables on the employer support received by migrants, Switzerland. Results of a logistic regression

\begin{tabular}{|c|c|c|c|}
\hline & B & S.E. & $\operatorname{Exp}(\mathrm{B})$ \\
\hline \multicolumn{4}{|l|}{ Level of qualification (ref = highly qualified)) } \\
\hline Less qualified & $-0.80 * * *$ & 0.09 & 0.45 \\
\hline \multicolumn{4}{|l|}{ Gender $($ ref $=$ man $)$} \\
\hline Woman & $-0.43 * * *$ & 0.10 & 0.65 \\
\hline \multicolumn{4}{|l|}{ Relationship status (ref $=$ in a relationship) } \\
\hline Not in a relationship & $-0.17^{+}$ & 0.10 & 0.84 \\
\hline Interaction term (gender $*$ relationship status) & $0.55 * * *$ & 0.15 & 1.73 \\
\hline \multicolumn{4}{|l|}{ Nationality $(\mathrm{ref}=\mathrm{US})$} \\
\hline Germany & $-1.35 * * *$ & 0.32 & 0.26 \\
\hline France & $-1.54 * * *$ & 0.32 & 0.21 \\
\hline Italy & $-1.17 * * *$ & 0.32 & 0.31 \\
\hline Austria & $-1.36^{* * *}$ & 0.36 & 0.26 \\
\hline Spain & $-1.20 * * *$ & 0.35 & 0.30 \\
\hline Portugal & $-1.83 * * *$ & 0.33 & 0.16 \\
\hline UK & -0.40 & 0.36 & 0.67 \\
\hline Canada & -0.74 & 0.48 & 0.48 \\
\hline India & -0.13 & 0.43 & 0.88 \\
\hline West Africa & $-2.12 * * *$ & 0.53 & 0.12 \\
\hline Other Latin American Countries & $-1.23 * *$ & 0.40 & 0.29 \\
\hline Brazil & $-1.21 * *$ & 0.44 & 0.30 \\
\hline Other & $-2.06 * * *$ & 0.52 & 0.13 \\
\hline \multicolumn{4}{|l|}{ Professional sector (ref = financial and insurance activities) } \\
\hline Agriculture, forestry and fishing & -0.37 & 0.32 & 0.69 \\
\hline Manufacturing, mining and quarrying and other industry & 0.27 & 0.17 & 1.32 \\
\hline Construction & $-0.45 * *$ & 0.18 & 0.64 \\
\hline Wholesale and retail trade, transportation, hotels and restaurants & $-0.29^{+}$ & 0.17 & 0.75 \\
\hline Information and communication & $-0.81 * * *$ & 0.19 & 0.45 \\
\hline $\begin{array}{l}\text { Professional, scientific, technical, administration and support } \\
\text { service activities }\end{array}$ & -0.19 & 0.17 & 0.82 \\
\hline $\begin{array}{l}\text { Public administration, defence, education, human health and } \\
\text { social action }\end{array}$ & $-0.61 * * *$ & 0.16 & 0.55 \\
\hline Other activities and services & $-0.38 *$ & 0.16 & 0.68 \\
\hline
\end{tabular}

Note: ${ }^{+} \mathrm{p}<.1{ }^{*} \mathrm{p}<.05 . * * \mathrm{p}<.01 . * * * \mathrm{p}<.001$. Model controlled for possession of a job or a job offer in Switzerland before the migration, age, presence of children and occupational status. The accuracy of the model is $71.3 \%$, for 4347 observations. The Nagelkerke $\mathrm{R}^{2}$ is 0.259 Source: Migration-Mobility Survey 2016. Weighted results 
employer is approximately halved for less qualified people compared with highly qualified people. However, the model also shows that the qualification level is by far not the only relevant variable to explain access to employers' support. In particular, the effect of most nationalities is higher than the effect of the qualification level, indicating that a low qualified American has for instance a higher probability of receiving support than does a highly qualified West African.

The effect of gender is significant and indicates a clear disadvantage for women compared with men concerning access to employers' support. According to the model, women have an approximately 35\% lower probability of receiving support than men do. However, we observe that this disadvantage is specific to the women relocating with their partner because the fact of being a single woman cancels out the disadvantage of being a woman. In contrast, men in a relationship experience no significant disadvantage. We thus observe that, even when all of the other variables are equal, women with a partner receive less support from their employer than single women do or than men do, whether single or in a relationship.

Nationality strongly affects access to employers' support. As expected, US nationals occupy a particularly favourable position because they receive more support than do any of the other nationalities except for people from the United Kingdom, Canada and India, for whom the results are not significantly different. The more disadvantaged nationalities with respect to employers' support are the West Africans and the Portuguese, who appear to have a greater than six times lower probability of receiving support from their employers compared with the Americans, even when they have a similar level of qualifications, work in a similar field and have a similar occupational status. It is interesting however that the model does not clearly differentiate between EU/EFTA and non-EU nationals. As expected, people from neighbouring countries receive relatively little support, but this point is also true for people from West Africa and Latin America. In contrast, English-speaking people from both EU/EFTA and third-countries (except for West Africans) have a clear advantage in accessing employers' support.

Differences between professional sectors are less pronounced than for the other variables. However, we observe that people working in the financial sector occupy a particularly favourable position for accessing employers' support. In contrast, people with state-related professions (public administration, defence, education, human health and social action) and with jobs that necessitate specific local skills (information and communication) have approximately a 50\% lower probability of being supported by their employer. The sectors that most notably rely on low qualified migrant workers (e.g., hotels, restaurants, and construction) also appear to invest less in relocation support. 


\subsection{Discussion}

The statistical analysis investigated the role of employers in providing support to immigrants. To the extent that relocation support is a tool that enables employers to attract economically profitable employees, observing which categories of people receive more support gives us information about who has more power to negotiate advantageous relocation conditions and, in this sense, represents a more "wanted" category for profit-oriented actors.

A first important finding is that employers grant less relocation support to nonsingle women compared with men and single women. Traditional representations of gender roles thus interact with corporate systems and mobile ways of life, influencing the type of resource that individuals can access depending upon both their gender and family situation. This finding reinforces the argument already introduced by Brandén et al. (2018) that employer recruitment choices contribute to the trailing spouse phenomenon by favouring the relocation of men over that of women. Our analysis adds to this argument by pointing to the crucial importance of the interaction between gender and relationship status. It suggests the existence of a dynamic that specifically disadvantages non-single women; if employers are reluctant to supporting non-single female employees because they fear that the relocation will fail due to the partner's bad adjustment (Mancini-Vonlanthen 2016; Salamin and Hanappi 2014), then they also increase the risk that the relocation will fail. As other authors have shown, corporate support has a positive effect on accompanying partners' adjustment and well-being (Grant-Vallone and Ensher 2001; ManciniVonlanthen 2016). By providing less support to accompanied women, the employers contribute to reproducing a self-fulfilling prophecy because they create a lower probability for their relocation to succeed compared with male-led relocations. This finding calls for more awareness about this phenomenon and for more research on the situation of couples in which the woman's job is the main driver of the relocation (Cangià 2017; Punnett et al. 1992).

Then, the data clearly show that employers do not treat all of the different nationalities similarly. This differentiation is not so surprising at first sight because the Swiss migration system creates different admission requirements for EU/EFTA and third-country nationals. Nevertheless, the differences are only loosely connected to immigration regulations. For instance, although both North America and West Africa are considered third-regions in Switzerland, the probability of receiving support from an employer is approximately eight times lower for West Africans than for Americans, even when they have a similar level of qualification, work in a similar professional sector and have a similar occupational status. Moreover, it is surprising that workers from West African and Latin American third-countries have on average a similar likelihood of receiving support from their employer compared with most EU/EFTA nationals because the former category of people is supposed to be more strictly selected by employers than the latter. The absence of clear differences thus suggests a disadvantage for the third-country nationals from these regions 
because the support of an employer is much more crucial for them than for Europeans due to the restrictive dual immigration system.

Finally, the analysis points to the importance of considering differences between activity sectors. It shows that people with similar characteristics receive different forms of support depending upon their job. This variation is currently not addressed as a political concern given the demand-driven focus of the Swiss immigration policy and the importance granted to immediate economic needs. Nevertheless, in a country that largely benefits from the expertise and knowledge of migrants, understanding the specific needs of different groups of migrants, developing programmes to address them and taking action to promote access to equal opportunities appear as crucial issues for the future.

\subsection{Conclusions}

This chapter focussed on the situation of recent migrants coming to Switzerland from a selected set of countries. We wanted to understand how access to employers' support is structured and who benefits more from it. We also wanted to critically address the construction of migrant categories by showing that employers create specific migration conditions for some people to whom they attribute an economic and social value that is partly independent of their actual skill level.

We used a combination of statistical and ethnographic methods to investigate differences in access to employers' support by recent immigrants. We showed on the one hand that employers actively attract some people to Switzerland, whereas on the other hand, different categories of migrants have unequal access to their support. The analysis revealed that, beyond the qualifications, social categories such as nationality and gender structure access to employers' support. Moreover, observing relationship status and professional sector is important for understanding differences in access to support.

A main finding of this analysis is that economic power relations between countries, gendered norms and recruitment practices within professional sectors all interact with immigration policies to create systems of inclusion and exclusion that enable highly qualified men from economically powerful countries to access significant corporate relocation support. Although this finding corresponds to the stereotype of the "expat" as a highly qualified man from a rich Anglo-Saxon country, it also shows that highly qualified men from rich Anglo-Saxon countries are actively given the possibility to become "expats", whereas people with similar levels of qualification and experience but with a different gender, nationality or background have fewer opportunities to access support and migrate. In this sense, the very notion of "expat" is a construction that reflects power relations at a global level. However, we also observe that categories and power relations can change over time. For instance, highly qualified Indians currently appear to have a probability of obtaining support from their employer similar to the Americans and the British. This new phenomenon can in turn transform our perception of them into "expats" 
instead of "immigrants". This finding adds to the Migration-Mobility Nexus theoretical framework by showing that regimes of economically driven mobility and state-driven migration interact with each other dynamically, reproducing in some cases older forms of inclusion/exclusion but also creating new ones.

These findings bring us back to the discussion of the notion of "wanted" migrants at the beginning of this chapter. In the academic literature, a clear distinction is often made between high-skilled and low-skilled migrants. We tried to show, however, that skills are not all that matters. The possibility of using one's skills and being acknowledged for one's skills is linked not only to a person's characteristics but also to the social, economic and political context in which they are embedded. In that sense, how actors involved in supporting and controlling mobility view migrants and differentiate between categories has direct consequences for the personal experiences and biographies of individuals moving across borders because it contributes to creating more- or less-supportive resource environments for them. As Mawuna Remarque Koutonin reminded us, categories are not neutral because they can transform someone's life.

\section{References}

Al Ariss, A., \& Crowley-Henry, M. (2013). Self-initiated expatriation and migration in the management literature: Present theorizations and future research directions. Career Development International, 18(1), 78-96.

Amarelle, C., \& Nguyen, M. S. (2010). Migrations et économie. L'accès des étrangers à la vie économique : les normes et leur application. Bern: Stämpfli.

Boucher, A. (2007). Skill, migration and gender in Australia and Canada: The case of gender-based analysis. Australian Journal of Political Science, 42(3), 383-401.

Brandén, M., Bygren, M., \& Gähler, M. (2018). Can the trailing spouse phenomenon be explained by employer recruitment choices? Population, Space and Place (Online publication before inclusion in an issue), 24, 1-11. https://doi.org/10.1002/psp.2141.

Brookfield. (2016). Global mobility trends survey report. London: Brookfield Global Relocation Services.

Cangià, F. (2017). (Im)Mobility and the emotional lives of expat spouses. Emotion, Space and Society, 25(2017), 22-28.

Cartus. (2014). Talent management and the changing assignee profile (2013 Survey report). Cartus. Trends in Global Relocation.

Chaloff, J., \& Lemaitre, G. (2009). Managing highly-skilled labour migration: A comparative analysis of migration policies and challenges in OECD countries (OECD Social, Employment and Migration Working Papers, 79, pp. 1-55). Paris: Organisation for Economic Co-operation and Development.

Cranston, S. (2017). Expatriate as a 'Good' Migrant: Thinking through skilled international migrant categories. Population, Space and Place, 23(6), 1-12.

Cranston, S., Schapendonk, J., \& Spaan, E. (2017). New directions in exploring the migration industries: Introduction to special issue. Journal of Ethnic and Migration Studies, 44(4), 543-557.

Crompton, R., \& Lyonette, C. (2006). Work-life 'Balance' in Europe. Acta Sociologica, 49(4), 379-393. 
Dahinden, J. (2016). A plea for the 'de-migranticization' of research on migration and integration. Ethnic and Racial Studies, 39(13), 2207-2225.

Daune-Richard, A.-M. (2003). La qualification dans la sociologie française : en quête des femmes. In J. Laufer \& C. Marry (Eds.), Le travail du genre: Les sciences sociales du travail à l'épreuve des différences de sexe (pp. 138-150). Paris: La Découverte.

Davoine, E., \& Salamin, A. (2012). La rémunération des expatriés: Le point de vue européen d'un consultant Suisse. Gestion, 37(2), 34-37.

Davoine, E., Ginalski, S., Mach, A., \& Ravasi, C. (2015). Impacts of globalization processes on the Swiss National Business Elite Community: A diachronic analysis of Swiss Large Corporations (1980-2010). Research in the Sociology of Organizations, 43, 131-163.

De Haas, H., Natter, K., \& Vezzoli, S. (2016). Growing restrictiveness or changing selection? The nature and evolution of migration policies. International Migration Review (Online version before inclusion in an issue). https://doi.org/10.1111/imre.12288.

Fassin, D. (2011). Policing borders, producing boundaries. The governmentality of immigration in dark times. Annual Review of Anthropology, 40(1), 213-226.

Favell, A. (2008). Eurostars and eurocities. Free movement and mobility in an integrating Europe (Studies in urban and social change). Malden: Blackwell.

Favell, A., Feldblum, M., \& Smith, M. P. (2006). The human face of global mobility. A research agenda. In M. P. Smith \& A. Favell (Eds.), The human face of global mobility: International highly skilled migration in Europe, North America and the Asia-Pacific (pp. 1-25). New Brunswick: Transaction Publishers.

Findlay, A. M., McCollum, D., Shubin, S., Apsite, E., \& Krisjane, Z. (2013). The role of recruitment agencies in imagining and producing the 'good' migrant. Social \& Cultural Geography, 14(2), 145-167.

Gelatt, J. (2017). .The RAISE Act: Dramatic change to family immigration, less so for the employment-based system. http://www.migrationpolicy.org/news/raise-act-dramatic-changefamily-immigration-less-so-employment-based-system. Accessed 11 Sept 2017.

Grant-Vallone, E. J., \& Ensher, E. A. (2001). An examination of work and personal life conflict, organizational support, and employee health among international expatriates. International Journal of Intercultural Relations, 25(3), 261-278.

Groutsis, D., Van den Broek, D., \& Harvey, W. (2015). Transformations in network governance: The case of migration intermediaries. Journal of Ethnic and Migration Studies, 41(10), $1558-1576$.

Harvey, M., \& Wiese, D. (1998). The dual-career couple: Female expatriates and male trailing spouses. Thunderbird International Business Review, 40(4), 359-388.

Harvey, M., Napier, N., \& Moeller, M. (2009). Interpreting dual career couples' family lifecycles: Identifying strategic windows of global career opportunity. Research and Practice in Human Resource Management, 17(2), 14-35.

Harvey, W. S., Groutsis, D., \& Van den Broek, D. (2017). Intermediaries and destination reputations: Explaining flows of skilled migration. Journal of Ethnic and Migration Studies, 44, 644-662.

Haug, W., \& Müller-Jentsch, D. (2008). Die Neue Zuwanderung in Zahlen. In D. Müller-Jentsch (Ed.), Die Neue Zuwanderung: Die Schweiz zwischen. Brain-Gain und Überfremdungsangst (pp. 25-26). Zürich: NZZ Libro.

Hercog, M. (2014). Migration-development links in selected European destination countries. In G. Tejada, U. Bhattacharya, B. Khadria, \& C. Kuptsch (Eds.), Indian skilled migration and development (pp. 71-86). New Delhi: Springer.

Hercog, M., \& Sandoz, L. (2018a). Highly skilled or highly wanted migrants? Conceptualizations, policy designs and implementations of high-skilled migration policies. Migration Letters, 15(4), 453-460.

Hercog, M., \& Sandoz, L. (2018b). Selecting the highly skilled: Norms and practices in the Swiss admission regime for non-EU immigrants. Migration Letters, 15(4), 503-515. 
Iredale, R. (2001). The migration of professionals: Theories and typologies. International Migration, 39(5), 7-24.

Jenson, J. (1991). The talents of women, the skills of men: Flexible specialisation and women. In N. Jackson (Ed.), Skills formation and gender relations: The politics of who knows what (pp. 37-52). Victoria: Deakin University.

Kaufmann, V., Bergman, M. M., \& Joye, D. (2004). Motility. Mobility as capital. International Journal of Urban and Regional Research, 28(4), 745-756.

Kofman, E. (2014). Towards a gendered evaluation of (Highly) skilled immigration policies in Europe. International Migration, 52(3), 116-128.

Kofman, E., \& Raghuram, P. (2005). Gender and skilled migrants: into and beyond the work place. Geoforum, 36(2), 149-154.

Kunz, S. (2016). Privileged mobilities: Locating the expatriate in migration scholarship. Geography Compass, 10(3), 89-101.

Le temps. (2015, January 8). L'âge d'or des expatriés est révolu.

Mach, A., David, T., \& Bühlmann, F. (2011). La fragilité des liens nationaux: La reconfiguration de l'élite au pouvoir en Suisse, 1980-2010. Actes de la recherche en sciences sociales, 5(190), 79-107.

Mancini-Vonlanthen, N. (2016). Spouses and families of expatriates: A systematic literature review by correspondence analysis based on semantic segments (LIVES Working Paper, vol. 49, pp. 1-44), National Centre or Competence in Research LIVES. Lausanne, Switzerland. https://doi.org/10.12682/lives.2296-1658.2016.49

Parsons, C., Rojon, S., Samanani, F., \& Wettach, L. (2014). Conceptualising international highskilled migration (The IMI working paper series, 104), pp. 1-26.

Pavic, K. (2015). Expats? Who are they? Eine sprachliche und historische Spurensuche. http://zeitnah.ch/10516/expats-who-are-they-eine-sprachliche-und-historische-spurensuche/. Accessed 2 Feb 2016.

Phillips, A., \& Taylor, B. (1980). Sex and skill: Notes towards a feminist economics. Feminist Review, 6, 79-88.

Piguet, E. (2013). Les théories des migrations. Synthèse de la prise de décision individuelle. Revue Européenne des Migrations Internationales, 29(3), 141-161.

Punnett, B. J., Crocker, O., \& Stevens, M. A. (1992). The challenge for women expatriates and spouses: some empirical evidence. International Journal of Human Resource Management Review, 3(3), 585-592.

Ravasi, C., Salamin, X., \& Davoine, E. (2015). Cross-cultural adjustment of skilled migrants in a multicultural and multilingual environment: An explorative study on foreign employees and their spouses in the Swiss context. The International Journal of Human Resource Management, 26(10), 1335-1359.

Ruhs, M., \& Anderson, B. (2010). Who needs migrant workers? Labour shortages, immigration, and public policy. Oxford: Oxford University Press.

Salamin, X., \& Davoine, E. (2015). International adjustment of female vs. male business expatriates. A replication study in Switzerland. Journal of Global Mobility, 3(2), 183-212.

Salamin, X., \& Hanappi, D. (2014). Women and international assignments. Journal of Global Mobility, 2(3), 343-374.

Sandoz, L. (2016). The symbolic value of quotas in the Swiss immigration system. Highlights, e-magazine of the nccr - on the move, 1, 40-45.

Sandoz, L. (2018a). Understanding access to the labour market through migration channels. Journal of Ethnic and Migration Studies [Published online: 24 Jul 2018], 1-20. https://doi.org /10.1080/1369183X.2018.1502657

Sandoz, L. (2018b). Intermediaries, channels and privileges: A journey into the mobility of the 'Highly Skilled' towards Switzerland. PhD thesis: University of Basel.

Shachar, A. (2006). The race for talent: Highly skilled migrants and competitive immigration regimes. New York Law Review, 81(1), 148-206. 
Simon-Kumar, R. (2015). Neoliberalism and the new race politics of migration policy: Changing profiles of the desirable migrant in New Zealand. Journal of Ethnic and Migration Studies, 41(7), 1172-1191.

Sommer, I. (2016). Gleichwertigkeit prüfen? Die (Nicht-) Anerkennung ausländischer Qualifikationen und die symbolische Gewalt im transnationalen Bildungsfeld. In E. Arslan \& K. Borzay (Eds.), Symbolische Ordnung und Bildungsungleichheit in der Migrationsgesellschaft, Interkulturelle Studien (pp. 373-388). Wiesbaden: Springer.

Steinberg, R. (1990). Social construction of skill: gender, power and comparable worth. Work and Occupations, 17(4), 449-482.

Swiss Federal Council. (2002). Message concernant la loi sur les étrangers, FF 2002 3469. Bern: Swiss Confederation.

Swiss Federal Department of Foreign Affairs. (2017). Bilateral relations Switzerland-India. https://www.eda.admin.ch/eda/en/home/representations-and-travel-advice/india/switzerlandindia.html. Accessed 11 Nov 2017.

Tannock, S. (2011). Points of Prejudice: Education-based discrimination in Canada's immigration system. Antipode, 43(4), 1330-1356.

Tissot, F. (2018). A migration industry for skilled migrants: The case of relocation services. Migration Letters, 15(4), 545-559.

Urciuoli, B. (2008). Skills and selves in the new workplace. American Ethnologist, 35(2), 211-228.

Van den Broek, D., Harvey, W. S., \& Groutsis, D. (2015). Commercial migration intermediaries and the segmentation of skilled migrant employment. Work, Employment \& Society, 30(3), 523-534.

Wagner, A.-C. (1998). Les nouvelles élites de la mondialisation: Une immigration dorée en France. Paris: Presses Universitaires de France.

Wagner, A.-C. (2007). Les classes sociales dans la mondialisation. Paris: La Découverte.

Wagner, A. C., \& Reau, B. (2015). Le capital international: un outil d'analyse de la reconfiguration des rapports de domination. In J. Siméant (Ed.), Guide de l'enquête globale en sciences sociales (pp. 33-46). Paris: CNRS éditions.

Xiang, B. (2007). Global 'Body Shopping': An Indian labor system in the information technology industry. Princeton: Princeton University Press.

Yeung, S. (2016). From cultural distance to skills deficit: "Expatriates", "Migrants" and Swiss integration policy. Multilingua, 35(6), 723-746.

Zschirnt, E., \& Ruedin, D. (2016). Ethnic discrimination in hiring decisions: A meta-analysis of correspondence tests 1990-2015. Journal of Ethnic and Migration Studies, 42(7), 1115-1134.

Open Access This chapter is licensed under the terms of the Creative Commons Attribution 4.0 International License (http://creativecommons.org/licenses/by/4.0/), which permits use, sharing, adaptation, distribution and reproduction in any medium or format, as long as you give appropriate credit to the original author(s) and the source, provide a link to the Creative Commons licence and indicate if changes were made.

The images or other third party material in this chapter are included in the chapter's Creative Commons licence, unless indicated otherwise in a credit line to the material. If material is not included in the chapter's Creative Commons licence and your intended use is not permitted by statutory regulation or exceeds the permitted use, you will need to obtain permission directly from the copyright holder.

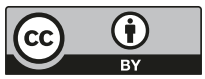

